СДН, розроблені на основі системи Moodle, можуть дати можливість вивчати матеріал з питань охорони праці у зручному тематичному форматі. Бази питань, які використовуються для створення тесту, наповнюються за допомогою гнучкого інтерфейсу. Цей інтерфейс має багато налаштувань щодо типу питання, відгуків/коментарів до питань чи відповідей, обмежень на перегляд підказок, нарахування балів за відповідь та інші механізми, що дозволяють отримати бажаний результат. Все це дозволяє забезпечити більш зручні можливості підготовки та складання екзамену студентами, а також об'єктивне оцінювання рівню засвоєних знань.

\title{
Посилання
}

[1] О. Г. Левченко, та О. С. Ільчук, “Аналіз та оцінка стану виробничого травматизму в галузі машинобудування”, Вісник Начіонального технічного університету Украйни «Київський політехнічний інститут» Серія «Гірництво», № 30, с. 171-176, 2016.

[2] К. Н. Ткачук, “Оцінка стану охорони праці у зварювальному виробництві за допомогою математичного моделювання”, Вісник Начіонального технічного університету Украӥни «Київський політехнічний інститут» Серія «Гірництво», № 25, с. 160-164, 2014.

[3] О. О. Кармазіна, Травматизм на виробництві. Київ, Україна: Держкомстат України, 2015.

[4] П. І. Федорук, “Адаптивна система дистанційного навчання та контролю знань на базі інтелектуальних Інтернет-технологій”, дис. докт. наук., Інститут проблем математичних машин і систем НАН України, Київ, Україна, 2009.

[5] В. М. Томашевський, Ю. Л. Новіков, та П. А. Камінська, “Огляд сучасного стану систем дистанційного навчання”, Наукові праиі: Науково-методичний журнал ЧДУ ім. Петра Могили. Комп'ютерні технологї̈, № 122, с. 146-157, 2011.

Стаття надійшла до редакиії 04.04.2017p.

УДК 620.91

DOI: $10.20535 / 2079-5688.0 .33 .99846$

В.П. Розен, проф., І.В. Яковчук, магістр, І.М. Шарий, магістр (КПІ ім. Ігоря Сікорського)
ОЦНЮЮАННЯ ЕНЕРГОЕФЕКТИВНОСТІ В НАВЧАЛЬНИХ ЗАКЛАДАХ 3 ВИКОРИСТАННЯМ ПРАВИЛ РАНЖУВАННЯ ЗА ПОКАЗНИКАМИ ВПЛИВУ НА РІВЕНЬ ЇХ ЕНЕРГОВИКОРИСТАННЯ 


\section{EVALUATION OF ENERGY EFFICIENCY IN EDUCATIONAL INSTITUTIONS USING THE RULES FOR INDICES RANGING IMPACT ON THE LEVEL OF ENERGY USE}

У роботі розглянуто механізм виявлення кращих зразків енергоефективності, який спирається на методи ранжування $i$ забезпечує достовірність управлінських дій спрямованих на підвищення рівня енергоефективності системи енергоспоживання в навчальних корпусах. Задачу підвищення енергоефективності запропоновано розглядати 3 позицій енергетичного бенчмаркінгу, який об'єднує задачі моніторингу, знаходження кращих i гірших аспектів системи, планування дій до підвищення ефективності енергозбереження та можливості їх застосування.

Ключові слова: бенчмаркінг; енергоефективність; ранжування; моніторинг; классифікація.

В работе рассмотрен механизм выявления лучших энергоэффективных обьектов, который опирается на методы ранжирования $u$ обеспечивает достоверность управленческих действий, направленных на повышение уровня энергоэффективности системы энергопотребления в учебных корпусах. Задачу повышения энергоэффективности предложено рассматривать с позиций энергетического бенчмаркинга, который объединяет задачи мониторинга, нахождения лучших и худших аспектов системы, планирование действий к повышению эффективности энергосбережения и возможности их применения.

Ключевые слова: бенчмаркинг; энергоэффективность; ранжирование; мониторинг; классификация.

This article examines a mechanism for identifying best examples of energy efficiency, based on ranking methods and ensures the reliability of management actions aimed at increasing energy efficiency of the power consumption system in educational buildings. The problem of energy efficiency offered to consider from the position of energy benchmarking that combines monitoring tasks, finding the best and worst aspects of planning actions to improve the efficiency of energy conservation and the possibility of their use.

Keywords: benchmarking; energy efficiency; ranking; monitoring; classification.

Вступ. Однією з актуальних проблем для України є підвищення рівня енергоефективності шляхом застосування нових підходів та методів для іiі оцінки i, як наслідок, зниження енерговитрат в промисловості та житлово комунальному господарстві [1]. В даний час, для оцінки реального стану енергозбереження на об'єктах існує цілий ряд різних за характером методів, механізмів і практичних заходів. Одним 3 таких досить нових управлінських механізмів $\epsilon$ використання методології бенчмаркінгу енергоефективності. Бенчмаркінг в рівній мірі включає два процеси: оцінювання і співставлення. Мета бенчмаркінгу полягає в тому, щоб на основі дослідження встановити потребу в змінах і досягнення успіху в результаті цих змін. Маючи в розпорядженні такий механізм, можна підвищити рівень адекватності 
планування споживання енергетичних ресурсів і обгрунтувати вибір об'єктів, по впровадженню заходів 3 енергозбереження. Для оцінки рівня ефективності використання енергетичних ресурсів за еталон, як правило, приймають "кращу" продукцію або технологічний процес, на які витрачається менше сировини i енергії, споживаної на аналогічних підприємствах в інших галузях. Тому, бенчмаркінг енергоефективності можна розглядати як один із напрямів стратегічно орієнтованих досліджень в галузі енергоефективності.

Аналіз стану питання. Україна належить до енергодефіцитних країн, яка задовольняє свої паливно - енергетичні потреби за рахунок власних ресурсів менш ніж на 50\% [2]. Енергоємність валового внутрішнього продукту в Україні нині більш ніж удвічі вища енергоємності такого продукту промислово розвинених країн і продовжує зростати. Тому стратегічною лінією державної політики розвитку економіки та соціальної сфери стає підвищення енергозбереження, що дає високу економічну ефективність.

Серед принципів забезпечення енергоефективності поряд iз впровадженням порівняльного аналізу (або бенчмаркінгу) відзначимо такі: виявлення ключових аспектів забезпечення енергоефективності та можливостей енергозбереження; послідовне вдосконалення енергоефективності (поетапне досягнення кращих показників); розробка та впровадження методів вдосконалення енергоефективності [3].

Ця політика реалізується шляхом розроблення нових енергозберігаючих, маловідходних та безвідходних технологій, ефективних систем та засобів контролю за енергоспоживанням та захисту довкілля від забруднення, організації інтегрованого енергетичного та економічного менеджменту.

Мета роботи. Метою роботи $є$ підвищення рівня якості оцінювання енергоефективності навчальних корпусів за рахунок виявлення кращих стратегій управління і моніторингу енергоефективністю.

Результати досліджень. Однією з основних складових підвищення рівня оцінювання енергоефективності в навчальних корпусах є здійснення дій щодо використання та впровадження адекватного оцінювання рівня їх енерговикористання та стану енергозбереження [4], [5]. Для цього потрібно застосовувати такий механізм оцінювання який би дозволив здійснювати оцінювання та аналіз різнопараметричних показників які мають неоднаковий вплив на ефективність енерговикористання.

Однак, під час рішення практичних задач оцінювання рівня ефективності енерговикористання часто виникає ситуація, коли показники по яким проводиться оцінювання не піддаються безпосередньому вимірюванню (мають різну "фізичну природу"). В цьому випадку вирішення поставленої задачі потребує використання таких процедур які б дозволили здійснити таке оцінювання.

До процедур що дозволяють вирішити задачу узагальнення різнорідних показників що мають вплив на рівень енергоефективності, можна віднести 
ранжування за рівнем якості енерговикористання [6]. Де ранжування - це упорядкування властивостей будь - яких якісних об'єктів, навчальних корпусів, під час якого їм надають певні числові форми.

Актуальним в цьому напрямку $\epsilon$ визначення універсальних правил проведення оціночних заходів, які охоплюють усі ключові напрямки відслідковування рівня ефективності енерговикористання за допомогою ранжування будівель. Результатом ранжування $\epsilon$ деяка кількість рейтингів, за допомогою яких і проводиться оцінка рівня ефективності енерговикористання.

Розглянемо правило Копленда, що полягає в наступному: створюється рейтинг, що підсумовує всі оцінки при порівнянні корпусу 3 іншими корпусами. Виходить, що рейтинг корпусу дорівнює різниці між числом корпусів краще даного і числом корпусів гірше даного, виходячи зі значень об'єктивних показників. Метод рекомендується використовувати, коли необхідно побудувати впорядковану думку більшості і дізнатися про кожен корпус, в порівнянні зі скількома корпусами він виграє або програє.

Для початку сформуємо матрицю спостережень. Початкова безліч складається 3 m об'єктів, описаних n критеріями; кожен іiі критерій можна інтерпретувати як точку n-мірного простору 3 координатами, рівними значенням n критеріїв для даного об'єкту. Матриця спостережень $X$ має такий вигляд:

$$
X=\left\|\begin{array}{|cccccc}
x_{11} & x_{12} & \ldots & x_{1 k} & \ldots & x_{1 n} \\
x_{21} & x_{22} & \ldots & x_{2 k} & \ldots & x_{2 n} \\
\ldots & \ldots & \ldots & \ldots & \ldots & \ldots \\
x_{i 1} & x_{i 2} & \ldots & x_{i k} & \ldots & x_{i n} \\
\ldots & \ldots & \ldots & \ldots & \ldots & \ldots \\
x_{m 1} & x_{m 2} & \ldots & x_{m k} & \ldots & x_{m n}
\end{array}\right\|
$$

Потім для значень, які включені в матрицю спостережень, виконуємо нормування показників за вхідними даними.

$$
a_{i j}^{H}=a_{i j} / \sum_{j-1}^{n} a_{i j}, i=\overline{1, m}, j=\overline{1, n} .
$$

Пронормовані значення показників X енергоефективності в навчальних корпусах наведені в таблиці 1, а парні порівняння виконані і відображені у таблиці 2.

В якості критеріїв для ранжирування використовуємо такі показники:

$\boldsymbol{x}_{1.1}$ - споживання електричної енергії навчальним корпусом протягом одного місяця;

$\boldsymbol{x}_{1.2}$ - споживання теплової енергії навчальним корпусом протягом одного місяця;

$\boldsymbol{x}_{1.3}$ - споживання води навчальним корпусом протягом одного місяця;

$\boldsymbol{x}_{1.4}$ - об'єм навчального корпусу;

$\boldsymbol{x}_{1.5}$ - теплові втрати навчального корпусу; 
$\boldsymbol{x}_{1.6}-$ середня кількість людей, що знаходяться в корпусі.

Таблиця 1

Проноровані значення показників X

\begin{tabular}{|l|c|c|c|c|c|c|}
\hline $\begin{array}{l}\text { Номер } \\
\text { корпусу }\end{array}$ & $\boldsymbol{x}_{1 . \boldsymbol{I}}$ & $\boldsymbol{x}_{1.2}$ & $\boldsymbol{x}_{1.3}$ & $\boldsymbol{x}_{1.4}$ & $\boldsymbol{x}_{1.5}$ & $\boldsymbol{x}_{\boldsymbol{1 . 6}}$ \\
\hline Корпус 1 & 0,128679 & 0,102413 & 0,081808 & 0,112885 & 0,037082 & 0,11314 \\
\hline Корпус 2 & 0,023023 & 0,03315 & 0,020309 & 0,015108 & 0,030031 & 0,006851 \\
\hline Корпус 4 & 0,048526 & 0,066167 & 0,032436 & 0,047348 & 0,035756 & 0,056347 \\
\hline Корпус 5 & 0,038459 & 0,04478 & 0,017366 & 0,03703 & 0,055783 & 0,054463 \\
\hline Корпус 6 & 0,061917 & 0,015103 & 0,035881 & 0,018146 & 0,005022 & 0,007947 \\
\hline Корпус 7 & 0,086426 & 0,125357 & 0,003158 & 0,149726 & 0,167289 & 0,100911 \\
\hline $\mathbf{\cdots}$ & $\ldots$ & $\ldots$ & $\ldots$ & $\ldots$ & $\ldots$ & $\ldots$ \\
\hline Корпус 30 & 0,018596 & 0,016091 & 0,005167 & 0,014303 & 0,005946 & 0,018497 \\
\hline Корпус 35 & 0,013732 & 0,005076 & 0,010621 & 0,003498 & 0,001948 & 0,00757 \\
\hline
\end{tabular}

Таблиця 2

Парні порівняння кількості переваг корпусів за правилом Кондорсе

\begin{tabular}{|c|c|c|c|c|c|c|c|c|c|c|c|}
\hline$K o p_{i} K o p_{k}$ & $\begin{array}{c}\overline{0} \\
\grave{0} \\
0 \\
0 \\
0\end{array}$ & 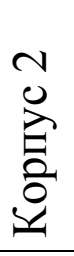 & 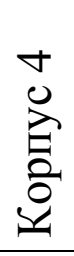 & $\begin{array}{l}n \\
0 \\
0 \\
0 \\
0 \\
0\end{array}$ & $\begin{array}{l}0 \\
0 \\
\vdots \\
0 \\
0 \\
0\end{array}$ & $\begin{array}{l}\hat{0} \\
0 \\
0 \\
0 \\
0 \\
0\end{array}$ & $\ldots$ & 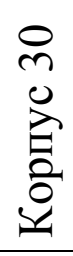 & $\begin{array}{l}n \\
\text { n } \\
0 \\
2 \\
0 \\
0 \\
0 \\
0\end{array}$ & $\begin{array}{l}\text { 㫕 } \\
\text { 总 } \\
\text { 运 }\end{array}$ & $\stackrel{\Xi}{\mathbb{E}}$ \\
\hline Корпус 1 & $X$ & 6 & 6 & 5 & 6 & 3 & $\ldots$ & 6 & 6 & 28 & 1 \\
\hline Корпус 2 & 0 & $X$ & 0 & 1 & 2 & 1 & $\ldots$ & 5 & 5 & 12 & 17 \\
\hline Корпус 4 & 0 & 6 & $X$ & 5 & 4 & 1 & $\ldots$ & 6 & 6 & 23 & 5 \\
\hline Корпус 5 & 1 & 5 & 1 & $X$ & 4 & 1 & $\ldots$ & 6 & 6 & 20 & 9 \\
\hline Корпус 6 & 0 & 4 & 2 & 2 & $X$ & 1 & $\ldots$ & 3 & 6 & 11 & 18 \\
\hline Корпус 7 & 3 & 5 & 5 & 5 & 5 & $X$ & $\ldots$ & 5 & 5 & 27 & 2 \\
\hline$\ldots$ & $\ldots$ & $\ldots$ & $\ldots$ & $\ldots$ & $\ldots$ & $\ldots$ & $\ldots$ & $\ldots$ & $\cdots$ & $\ldots$ & $\ldots$ \\
\hline Корпус 30 & 0 & 1 & 0 & 0 & 3 & 1 & $\ldots$ & $X$ & 5 & 9 & 20 \\
\hline Корпус 35 & 0 & 1 & 0 & 0 & 0 & 1 & $\ldots$ & 1 & $X$ & 2 & 27 \\
\hline
\end{tabular}


За цим правилом для кожного об'єкта знаходиться дві підмножини відносин Кондорсе:

1) Для $K o p_{i}$ підмножина $U\left(K o p_{i}\right)$, що складається з усіх їі домінантів;

2) Для $K o p_{i}$ підмножина $L\left(K o p_{i}\right)$, для яких вона є домінантою.

Після цього для кожного Кор $i$ розраховується коефіцієнт Копланда за формулою:

$$
\operatorname{Coop}\left(K_{o s}\right)=\left|L\left(K_{i} p_{i}\right)\right|-\left|U\left(K_{o} p_{i}\right)\right|, i=\overline{1, m} .
$$

За цими коефіцієнтами визначаємо рейтинг корпусів. Коефіцієнти Копленда наведені в таблиці 3. Графік рейтингу корпусів зображено на рисунку 1.

Таблиця 3

Визначення домінанти та кількісного показника ранжування

\begin{tabular}{|c|c|c|c|}
\hline № & $L\left(\right.$ Kop $\left._{i}\right)$ & $U\left(\right.$ Kop $\left._{i}\right)$ & $L-U$ \\
\hline Kорпус 1 & 0 & 28 & -28 \\
\hline Корпус 2 & 13 & 12 & 1 \\
\hline Корпус 4 & 3 & 23 & -20 \\
\hline$\ldots$ & $\ldots$ & $\ldots$ & 23 \\
\hline Корпус 35 & 25 & 2 & \\
\hline
\end{tabular}

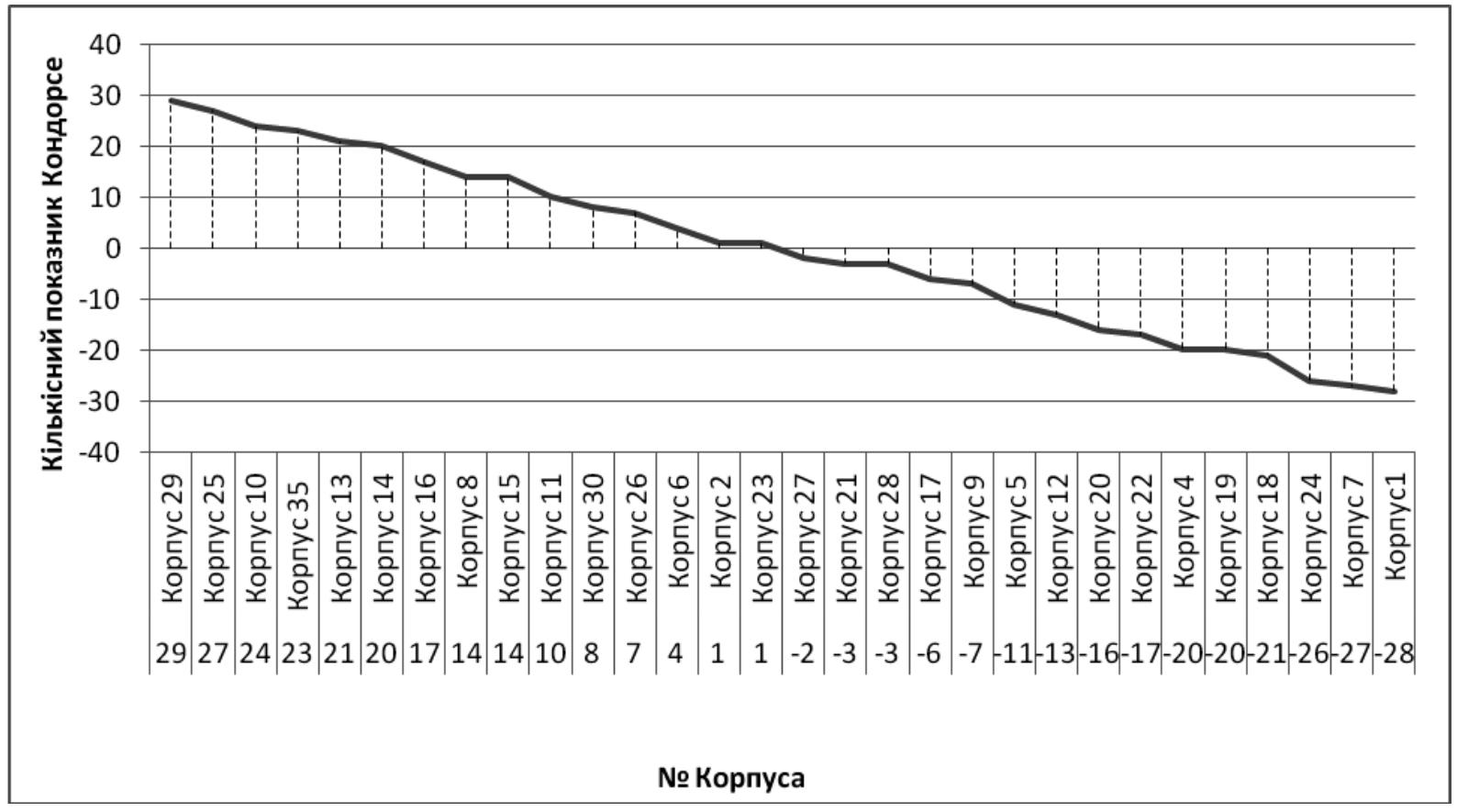

Рис. 1. Результати ранжування корпусів за правилом Копленда

Методи вибору, які засновані на парних порівняннях об'єктів (правила Кондорсе, Копленда) за всіма критеріями використовують факт домінанта 
одного корпусу над іншим, але не враховують того, на скільки сильним $є$ домінант. Використаємо уточнений методу парних порівнянь для оцінювання рівня ефективності енерговикористання у навчальних корпусах.

Запропоноване правило враховує цю різницю i сприяє більш «справедливому» (правильному) ранжуванню навчалиних корпусів, так як в цьому методі домінант Кор $_{i}$ над $K_{k} p_{k}$ по $j$ - ому критерію визначається «відстанню» між ними в упорядкованому переліку корпусів (табл. 4) по $j$ - ому критерію.

3 цього переліку розглянемо $K o p_{i k}, K o p_{i l}, k \neq l$ та введемо число:

$$
q_{i}\left(K_{o p}, K_{i k}\right)=\left\{\begin{array}{l}
l-k, \text { якщо } l>k \\
0, \text { якщо } l<k
\end{array}\right.
$$

Число $q_{i}\left(K_{o p}, K_{i k} p_{i l}\right)$ визначає ступінь переваги $K_{o p} p_{i k}$ над $K o p_{i l}$ по j - ому критерію, тобто вказує наскільки «віддалені» один від одного. Тоді перевагу (домінант) $\operatorname{Kop}_{i k}$ над $K o p_{i l}$ по всім критеріям можно виразити числом:

$$
Q_{i}\left(K o p_{i k}, K o p_{i l}\right)=\sum_{j=1}^{n} q_{i}\left(K o p_{i k}, K o p_{i l}\right)
$$

Частковий розрахунок значень матриці.

Числа в порівнянні взяті 3 порядкового номера Кор ${ }_{i}$ для кожного критерія в таблиці 4:

$q_{i}\left(K_{o p}, K_{o p}\right) 11>4 \Rightarrow 0 ; 9>1 \Rightarrow 0 ; 10>7 \Rightarrow 0 ; 15>5 \Rightarrow 0 ; 9>6 \Rightarrow 0 ; 24>4 \Rightarrow 0$

$Q_{i}\left(K_{o p}, K_{o p}\right)=0$;

$q_{i}\left(K_{o p}, K_{o p}\right) 11>6 \Rightarrow 0 ; 9>7 \Rightarrow 0 ; 10<12 \Rightarrow 2 ; 15>8 \Rightarrow 0 ; 9>4 \Rightarrow 0 ; 24>5 \Longrightarrow 0$

$Q_{i}\left(K_{o p}, K_{o p}\right)=2$;

Розрахувавши числа $Q_{i}\left(K o p_{i k}, K o p_{i l}\right)$ для всіх пар навчальних корпусів $\left(K o p_{i k}, K o p_{i l}\right)$, визначимо рейтинг $\bar{Q}\left(K o p_{i}\right)$ наступним чином:

$$
\bar{Q}\left(K_{o p}\right)=\sum_{j=1}^{m} Q_{i j}, j \neq 1, i=\overline{1, m}
$$

де $Q_{i j}$ - элементи матриці $Q_{i}\left(K_{o p} p_{i k}, K o p_{i l}\right)$.

Рейтингова оцінка $\bar{Q}\left(K_{o p}\right)$ - це сума $i$ - го рядку, яка відображена у таблиці 5. Графік рейтингу корпусів, що отримали за цим уточненим методом парних порівнянь зображений на рисунку 2.

Таблиця 4

Впорядкований перелік корпусів

\begin{tabular}{|l|l|l|l|l|l|l|}
\hline 1 & Корпус 19 & Корпус 4 & Корпус 8 & Корпус 19 & Корпус 20 & Корпус 18 \\
\hline 2 & Корпус 22 & Корпус 18 & Корпус 18 & Корпус 18 & Корпус 28 & Корпус 12 \\
\hline 3 & Корпус 6 & Корпус 20 & Корпус 10 & Корпус 27 & Корпус 9 & Корпус 22 \\
\hline
\end{tabular}


Продовження табл. 4

\begin{tabular}{|c|c|c|c|c|c|c|}
\hline 4 & Корпус 4 & Корпус 19 & Корпус 22 & Корпус 20 & Корпус 5 & Корпус 4 \\
\hline 5 & Корпус 12 & Корпус 27 & Корпус 19 & Корпус 4 & Корпус 21 & Корпус 5 \\
\hline 6 & Корпус 5 & Корпус 9 & Корпус 6 & Корпус 22 & Корпус 4 & Корпус 21 \\
\hline 7 & Корпус 20 & Корпус 5 & Корпус 4 & Корпус 12 & Корпус 19 & Корпус 20 \\
\hline 8 & Корпус 18 & Корпус 22 & Корпус 12 & Корпус 5 & Корпус 23 & Корпус 17 \\
\hline 9 & Корпус 17 & Корпус 2 & Корпус 20 & Корпус 9 & Корпус 2 & Корпус 19 \\
\hline 10 & Корпус 21 & Корпус 28 & Корпус 2 & Корпус 17 & Корпус 18 & Корпус 9 \\
\hline 11 & Корпус 2 & Корпус 17 & Корпус 17 & Корпус 28 & Корпус 22 & Корпус 16 \\
\hline 12 & Корпус 11 & Корпус 21 & Корпус 5 & Корпус 23 & Корпус 27 & Корпус 8 \\
\hline 13 & Корпус 9 & Корпус 23 & Корпус 28 & Корпус 6 & Корпус 17 & Корпус 15 \\
\hline 14 & Корпус 30 & Корпус 26 & Корпус 21 & Корпус 21 & Корпус 12 & Корпус 23 \\
\hline 15 & Корпус 28 & Корпус 12 & Корпус 23 & Корпус 2 & Корпус 26 & Корпус 30 \\
\hline 16 & Корпус 26 & Корпус 30 & Корпус 26 & Корпус 30 & Корпус 11 & Корпус 27 \\
\hline 17 & Корпус 35 & Корпус 6 & Корпус 35 & Корпус 26 & Корпус 30 & Корпус 28 \\
\hline 18 & Корпус 27 & Корпус 14 & Корпус 11 & Корпус 11 & Корпус 6 & Корпус 14 \\
\hline 19 & Корпус 15 & Корпус 11 & Корпус 9 & Корпус 8 & Корпус 13 & Корпус 25 \\
\hline 20 & Корпус 23 & Корпус 15 & Корпус 27 & Корпус 15 & Корпус 15 & Корпус 11 \\
\hline 21 & Корпус 8 & Корпус 16 & Корпус 30 & Корпус 13 & Корпус 8 & Корпус 26 \\
\hline 22 & Корпус 16 & Корпус 8 & Корпус 16 & Корпус 16 & Корпус 14 & Корпус 6 \\
\hline 23 & Корпус 13 & Корпус 13 & Корпус 14 & Корпус 14 & Корпус 16 & Корпус 35 \\
\hline 24 & Корпус 14 & Корпус 25 & Корпус 15 & Корпус 10 & Корпус 10 & Корпус 2 \\
\hline 25 & Корпус 10 & Корпус 35 & Корпус 13 & Корпус 35 & Корпус 35 & Корпус 29 \\
\hline 26 & Корпус 29 & Корпус 10 & Корпус 25 & Корпус 25 & Корпус 25 & Корпус 10 \\
\hline 27 & Корпус 25 & Корпус 29 & Корпус 29 & Корпус 29 & Корпус 29 & Корпус 13 \\
\hline
\end{tabular}

Таблиця 5

Рейтингова оцінка корпусів

\begin{tabular}{|c|c|c|c|c|c|c|c|c|c|c|}
\hline$K o p_{i} K o p_{k}$ & $\begin{array}{l}N \\
0 \\
\grave{2} \\
0 \\
0 \\
0\end{array}$ & $\begin{array}{l}+ \\
0 \\
\grave{\lambda} \\
0 \\
0 \\
0\end{array}$ & $\begin{array}{l}n \\
0 \\
2 \\
0 \\
0 \\
0 \\
1\end{array}$ & 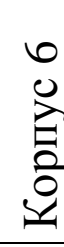 & 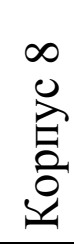 & $\begin{array}{l}a \\
0 \\
0 \\
0 \\
0 \\
0\end{array}$ & $\cdots$ & 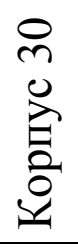 & 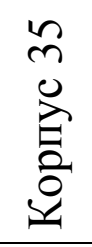 & $\bar{Q}\left(K o p_{i}\right)$ \\
\hline Корпус 2 & $X$ & 0 & 2 & 17 & 39 & 11 & $\ldots$ & 30 & 55 & 715 \\
\hline Корпус 4 & 51 & $X$ & 17 & 54 & 75 & 36 & $\ldots$ & 72 & 105 & 1597 \\
\hline Корпус 5 & 38 & 2 & $X$ & 46 & 65 & 20 & $\ldots$ & 57 & 90 & 1280 \\
\hline Корпус 6 & 16 & 2 & 9 & $X$ & 32 & 23 & $\ldots$ & 29 & 53 & 751 \\
\hline Корпус 8 & 21 & 6 & 11 & 15 & $X$ & 18 & $\ldots$ & 23 & 40 & 564 \\
\hline Корпус 9 & 29 & 3 & 2 & 42 & 54 & $X$ & $\ldots$ & 39 & 74 & 996 \\
\hline
\end{tabular}


Продовження табл. 5

\begin{tabular}{|c|c|c|c|c|c|c|c|c|c|c|}
\hline$K o p_{i} K K_{k} p_{k}$ & $\begin{array}{l}N \\
0 \\
2 \\
0 \\
0 \\
0 \\
0\end{array}$ & 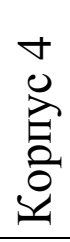 & $\begin{array}{l}n \\
0 \\
0 \\
0 \\
0 \\
0 \\
\vdots\end{array}$ & 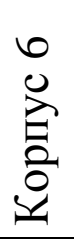 & 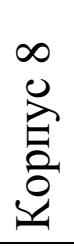 & 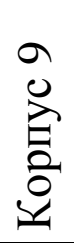 & $\ldots$ & $\begin{array}{l}\circ \\
0 \\
0 \\
\grave{0} \\
0 \\
0\end{array}$ & $\begin{array}{l}n \\
n \\
0 \\
0 \\
0 \\
0 \\
0\end{array}$ & $\bar{Q}\left(K_{o p}\right)$ \\
\hline$\cdots$ & $\ldots$ & $\ldots$ & $\cdots$ & $\cdots$ & $\cdots$ & $\cdots$ & $\cdots$ & $\ldots$ & $\ldots$ & $\ldots$ \\
\hline Корпус 30 & 9 & 0 & 0 & 9 & 20 & 0 & $\ldots$ & $X$ & 37 & 377 \\
\hline Корпус 35 & 1 & 0 & 0 & 0 & 4 & 2 & $\ldots$ & 4 & $X$ & 129 \\
\hline
\end{tabular}

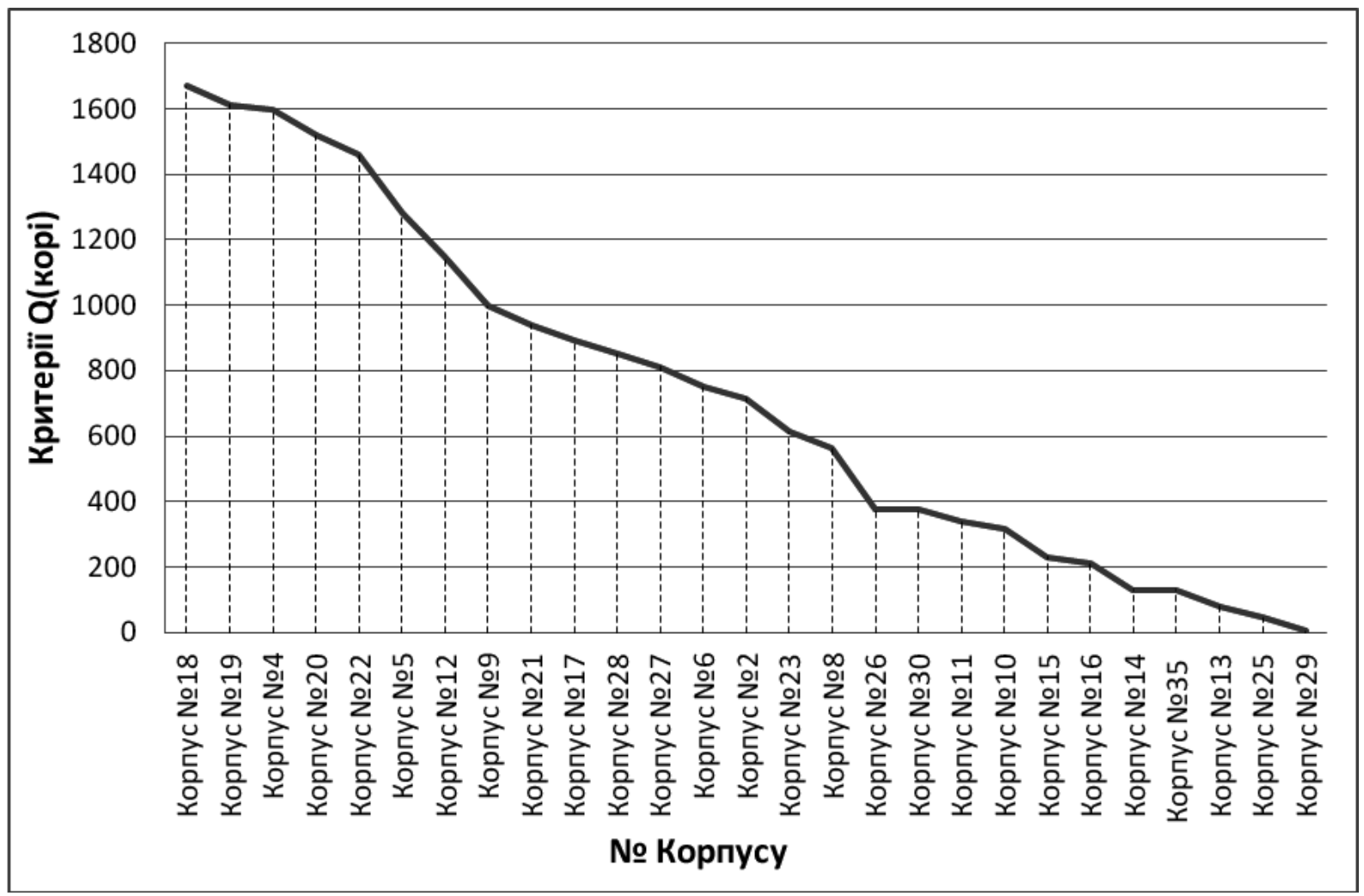

Рис. 2. Результат ранжування корпусів уточненим методом попарних порівнянь

Результати проведених ранжувань, використовуючи метод Копленда та уточнений метод парних порівнянь дають нам змогу визначити рейтинг енегроефективності навчальних корпусів та відокремити певну кількість будівель в яких рівень енерговикористання найгірший. Використовуючи отримані результати можна запроваджувати організаційні та управлінські заходи щодо покращення стану енерговикористання у проблемних корпусах. 


\section{Висновки}

1. Рейтинг є інструментом, використання якого, дозволяє отримувати інформацію щодо якості оцінюваної системи енерговикористання, стимулювати для здійснення дій 3 поліпшення стану справ у сфері енергоефективності, здійснювати взаємодію між різними суб'єктами відносин і контролювати процес досягнення задачі енергетичного бенчмаркінгу підвищення рівня ефективності енерговикористання.

2. Бенчмаркінг $€$ невід'ємною частиною планування, аналізу та оцінки процесу, тобто моніторингу, а також інструментом управління для безперервного поліпшення. Включення процедур бенчмаркінгу в систему енергетичного менеджменту сприяє виявленню шляхів підвищення рівня енергоефективності з урахуванням досягнень кращих об'єктів. Систематичне визначення різниці в енергоспоживанні та розривів з кращою практикою, визначення та реалізація заходів щодо підвищення рівня енергоефективності, моніторинг результатів впровадження і переоцінка результатів бенчмаркінгу $\epsilon$ частиною циклу постійного удосконалення виробничої системи, що сприяє покращенню енергетичного функціонування та підвищення рівня іiі енергоефективності.

3. Запропонована модель оцінювання енергоефективності навчальних корпусів передбачає створення та підтримку відповідно пристосованих систем збору та моніторингу інформації по споживанню енергії, методів оцінювання ефективності енергоспоживання 3 їх супроводом та налаштуванням до умов практичної реалізації, використання поглиблених схем енергоаудиту на базі інтегрованих енергетичних моделей об'єктів та розвитку детальних інструментальних та розрахункових досліджень енергетичного стану елементів будівель.

\section{Посилання}

[1] Л.В. Давиденко, Механізм бенчмаркінгу енергоефективності об'єктів складних виробничих систем та принципи його реалізаиії. Київ, Україна: Енергозбереження. Енергетика. Енергоаудит, 2015.

[2] В.П. Розен, та Б.Л. Тишевич, Методологія бенчмаркінгу енергоефективності для промисловості Укрї̈ни. Київ, Україна: Енергозбереження. Енергетика. Енергоаудит, 2012.

[3] А.В. Бобряков, Разработка и реализачия научно - технических и управленческих методов повышения энергоэффрективности отраслевого энергопотребления бюджетной сферы. Москва, Россия: «Пром.теплоэнергетика», 2007.

[4] В.Ф. Ткаченко, Моніторинг спожсивання електроенергї інфраструктурою вищого навчального закладу (на прикладі Черкаського державного 
технологічного університету). Київ, Україна: НАН України, Інститут техн. теплофізики, 2014.

[5] ISO 50001:2011. Energy management systems - Requirements with guidance for use - CEN/CENELEC. European Committee for Standardization, 2011.

[6] В.П. Розен, А.И. Соловей, та А.В. Чернявский, Разработка концепции внедрения системы энергетического менеджмента на промышленных предприятиях Украиныл. Киев, Украина: Праці ІЕД НАНУ, № 1(10), 2005.

Стаття надійила до редакиїі 21.04.2017p. 